\title{
WINTER FROST DAMAGE AND ITS LINK TO EARLY GROWTH AND SURVIVAL IN A POPLAR CLONE COLLECTION
}

\author{
*Silva Šēnhofa, Dagnija Lazdiṇa, Mārtiņš Zeps \\ Latvian State Forest Research Institute 'Silava', Latvia \\ *Corresponding author’s email: silva.senhofa@silava.lv
}

\begin{abstract}
The Northern European countries largely rely on poplars and their hybrids that are transferred northward from more southern regions, therefore, facing a trade-off between the use of full growth potential and sufficient tolerance of low temperatures. We characterized frost damage and its link to early growth and survival of 33 poplar genotypes at the age of one, three, and four years in a clonal collection on agricultural land. The survival after the first season varied from $42 \%$ to $99 \%$. Half of the clones had autumn frost injuries with a maximum of $20 \%$ of trees damaged. The autumn frost-damaged trees were significantly $(\mathrm{p}<0.001)$ higher before the injury than the undamaged trees with site mean $105.3 \pm 7.9$ and $72.0 \pm 2.5 \mathrm{~cm}$, respectively, but, at the clone mean level, the proportion of autumn frost-damaged trees had no link to survival $(\mathrm{rho}=0.53, \mathrm{p}<0.001)$. The observed winter frost damage showed no relation $(\mathrm{p}<0.05)$ regarding the proportion of trees with autumn frost damage. Trees with winter frost damage tended to be shorter than undamaged trees $(\mathrm{p}<0.001)$ and had lower survival $(\mathrm{rho}=0.47, \mathrm{p}<0.01)$. The maximum height difference of the clones among the studied years was in a magnitude from 2.4 to 2.9 , and the stability of a clonal ranking increased with the age. The results emphasize the need for further monitoring of the clone performance under the local climatic conditions before recommendations of commercial use of particular clones in Latvia.
\end{abstract}

Key words: Clonal ranking, cold injury, maladaptation, Populus hybrids.

\section{Introduction}

Traditional forestry is facing challenges to satisfy expanding global demand for the production of raw materials from sustainable, renewable natural resources. Roundwood and bioenergy production by fast-growing species outside the natural forests pose the potential to produce substantial yield on the limited land area (Jürgensen, Kollert, \& Lebedys, 2014; Mola-Yudego et al., 2017). This allows to efficiently preserve sequestrated $\mathrm{CO}_{2}$ and substitute fossil fuels thereby mitigating climate change (Sulaiman, AbdulRahim, \& Ofozor, 2020) and reducing the pressure on natural forests (Pawson et al., 2013) that might be not very efficient in providing this ecosystem service (Ķēniņa et al., 2018, 2019a, 2019b).

Species and hybrids of the Populus genus are shown to be among the most promising fast-growing tree species in the boreal and hemiboreal region (Rytter et al., 2013) with a mean annual increment of up to 20 $\mathrm{m}^{3}$ ha $^{-1}$ year $^{-1}$ in a rotation of 25 years (Rytter \& Stener, 2014). Besides, the assessed species had demonstrated notable resistance to main damaging agent in Northern Europe - wind (Čakša et al., 2021; Samariks et al., 2020, 2021). The plantation productivity primarily depends on the performance of selected genotypes. Although poplars represent a rather wide genetic basis and are easy to vegetatively propagate, in comparison to other species (Gailis et al., 2021), there is very limited adapted planting stock available in Europe. Large areas are established using exclusively a few superior clones, such as OP42 in Denmark (Stener \& Westin, 2017) and Sweden (Karacic et al., 2020) and I-214 in southern Europe (FAO, 2016), posing concerns related to climate change and pest or disease resistance. Currently, there is a breeding program for poplars and 16 clones already selected and tested for commercial use in Sweden (Stener \& Westin, 2017). Other countries in the north of Europe fully rely on material that is bred and imported from more southern regions, mainly Italy and Germany (Niemczyk et al., 2018). The northward transfer, however, might result in a trade-off between the use of full growth potential and sufficient frost tolerance. Too early or late growth onset and cessation leads to suboptimally used growing season (Jansons et al., 2014; Gailis et al., 2019; Skrøppa \& Magnussen, 1993; Zeltiņš et al., 2019), meanwhile increasing the risk of cold injuries (Howe et al., 2000; Junttila \& Kaurin, 1990). Injuries might be affected both by genotype (clone) and growth rate (Šēnhofa et al., 2016; Zeltiņš et al., 2016). Additionally, crossbreeding alters genotypically controlled adaptive traits of a parental species and hybrids from different regions (Gudynaitè-Franckevičienè, Pliūra, \& Suchockas, 2020), hence, imposing the importance of genotype testing under local conditions before their application at a commercial scale (Jansons et al., 2018; Lazdina et al., 2016, Senhofa et al., 2017; Pliura et al., 2014).

This study aimed to characterize susceptibility to frost and its link to early growth and survival of 33 poplar genotypes with a different source of origin for the first four years in a clonal collection on agricultural land. We intended to assess their early performance under low agricultural impact.

\section{Materials and Methods}

The study was carried out in a clonal collection in Kalsnava ( $56^{\circ} 41^{\prime} \mathrm{N}, 25^{\circ} 58^{\prime} \mathrm{E}$ ), Latvia, established on abandoned agricultural land (heavy stony clay soil) in the spring 2016. In total, 34 poplar clones from 
the Aigeiros and Tacamahaca sections of the genus Populus were represented. Subsets of the clones have Swedish, Italian, and German origin, and together with the clone OP42 (synonym Hybride275 for the same clone), they have been introduced recently, during the last 10 to 15 years. The collection also includes clones collected across Latvia. These are progenies (cuttings) of the poplars that survived after introduction, presumably, in the 1960s, but the origin of these clones is unknown. Per each clone, 97 to 102 cuttings (about $25 \mathrm{~cm}$ length) were planted in narrow spacing mono-clonal rows with $350 \mathrm{~cm}$ between the rows and $50 \mathrm{~cm}$ between individual plants in a row (that makes up 5,714 trees per ha) with no replications within a small area. The site was prepared by inverted soil scarification before the planting but thereafter received minimal agricultural impact with exception of weed control by rotary brush hog mower between tree rows. The plantation was fenced.

In the spring 2017, tree survival and damage (autumn frost injuries, browsing damage, dead or undamaged) were assessed, and the height of all living trees was measured (except for Clone OP42). All trees had developed only a single stem.

In the spring 2018, winter frost damage was assessed. Clones were visually evaluated on a fivescale grade: 0 - dead, 1 - severe damage, 2 - mild damage, tree recovers, 3 - minor damage, and 4 - no visible winter frost damage.

In the spring 2019, the height of all live trees was measured. In the spring 2020, the height was measured for every second tree in a row.

The normality of data was assessed by the ShapiroWilk test. The differences in height among the clones and their origins were assessed by nonparametric Kruskal-Wallis, followed by the Dunn test for pairwise comparisons. Mann-Witney U test was used for pairwise clone height comparison for damaged and undamaged trees. Relations between tree and clone parameters were assessed by Spearman's rank correlation. All tests were performed in R (version 4.0.2), at $\alpha=0.05$. Mean values $\pm 95 \%$ confidence interval are showed throughout the paper.

\section{Results and Discussion}

Tree survival after the first season was $82 \%$ ( site mean), and varied from $42 \%$ for clone AF18 to $99 \%$ for clones Max1 and Max3 (Figure 1). The average survival of the clonal collection was similar or higher than was found in trials on agricultural land in Denmark at the age of three and Southern Sweden at the age of four years (52 to $89 \%$ ) for a clonal set that partly overlapped with our study (Stener \& Westin, 2017). However, several clones had more than one-third of cuttings dead already after the first growing season. The design of a clonal collection might pose risks of low survival due to microclimatic differences as there was only one replication per clone. However, the studied site was a flat and homogeneous field and no pattern in the spatial distribution of low high mortality was present, suggesting that the microclimatic differences are unlikely to be a cause of mortality.

A high proportion of trees was browsed (site mean $59 \%$ ). The damage was present for all clones and occurred in the winter when a fence was accidentally left unlocked allowing access for wild ungulates. Browsing is a widespread problem in Populus plantations that might contribute to low vitality and hence increase mortality. However, not all Populus clones are browsed to the same extent: the proportion of damaged trees varied from $16 \%$ to $91 \%$, and 24 out of 33 clones had more than half of the trees browsed. Several feeding experiments have confirmed underlying differences in preference of clones due to plant macronutrient and mineral content (Holeski et al., 2016) and phytochemical defences (Lastra, Kenkel, \& Daayf, 2017).

Results at the beginning of the second growing season revealed that several clones might be sensitive to the local climate as half of the clones (16 out of 33) had cold injuries at the beginning of the second growing season. An inappropriate adaptation is a common concern for the low survival of introduced clones (Gudynaitè-Franckevičienè, Pliūra, \& Suchockas, 2020; Karacic et al., 2020; Schreiber et al., 2013). The differences in autumn frost damage are likely related to clonal differences in the timing of bud set (Friedman et al., 2008; Howe et al., 2000) that is typically found to be highly heritable (Pliura et al., 2014), thus, differ among the genotypes.

Indeed, while most of the clones were damaged scarcely (median of the proportion of damaged trees $4 \%$ ), genotypes of certain families were more susceptible to sudden temperature drop than others. In our site progenies of $P$. maximowiczii $\times P$. trichocarpa had suffered from autumn frost substantially more than other clones with the proportion of damaged trees $12 \%$ for Hybride 275, 14\% for Matrix 24, and 20\% for Matrix11. However, while maladaptation might be related to the high mortality of northward-transferred clones, it seems an incongruous explanation for the high mortality of locally collected clone Pop1. The ortet of this clone was introduced in Latvia decades ago and has shown reasonable growth to be selected for progeny testing; therefore, presumably it should not be severely negatively affected by local climatic conditions.

Neither browsing, nor autumn frost damage was negatively related to survival (rho $=-0.02, \mathrm{p}>0.05$ and rho $=0.53, \mathrm{p}<0.001)$. However, only one-fifth (site mean $21 \%$ ) of trees were alive and undamaged after the first growing season. Clones P0114 and 


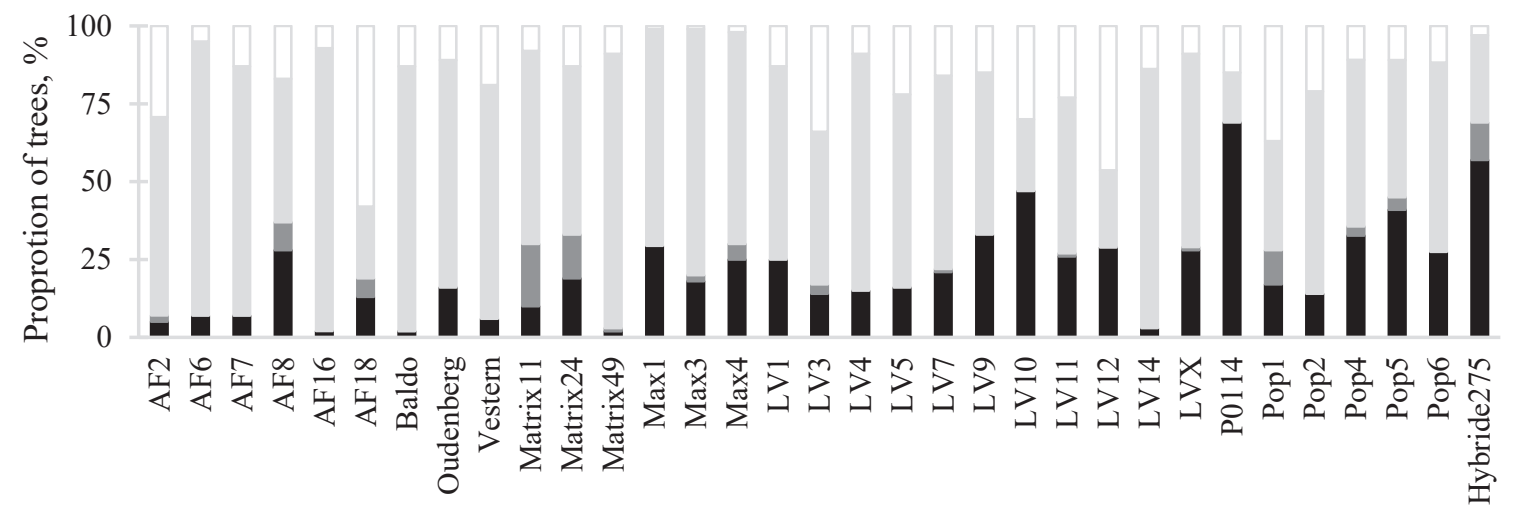

Clone

Figure 1. The damage of clones after the first growing season. Colour of the stacked bars: black - undamaged trees, dark grey - autumn frost-damaged trees, light grey - browsed trees, white - dead trees.

Hybride 275 had a notably higher proportion $(69 \%$ and $57 \%$, respectively) of undamaged trees than the others, whereas eight of the clones had less than $10 \%$ of such trees.

There was no link between autumn frost damage and survival, suggesting that autumn frost damages unhardened shoots but not to an extent that affects plant survival. However, the effect of frost injuries depends on the timing and severity of frost and might be more severe in case of a more extreme temperature drop. This was shown in a recent study of simulated spring frost where $40 \%$ mortality of $P$. maximowiczii $\times P$. trichocarpa hybrids and $45 \%$ mortality of $P$. deltioides $\times P$. trichocarpa hybrids was observed for two-year-old trees (Gudynaite-Franckevičienè, Pliūra, \& Suchockas, 2020).

Tree survival showed a significant positive link to height $(\mathrm{rho}=0.67, \mathrm{p}<0.001)$. At the clone mean level, there was no relationship between height and proportion of autumn frost-damaged (rho $=0.42, \mathrm{p}>0.05$ ) trees. However, the autumn frost-damaged and browsed trees were significantly (both $\mathrm{p}<0.001$ ) higher than the undamaged trees with site mean $105.3 \pm$ $7.9,83.0 \pm 1.2$, and $72.0 \pm 2.5 \mathrm{~cm}$, respectively. The autumn frost-damaged trees were markedly longer compared to the intact trees, suggesting that fastgrowing trees are more susceptible to frost at the end of the growing season. It is consistent with previous findings of trees that set buds later are higher, yet, also more prone to frost injuries (Pliura et al., 2014). Although we lack repeated assessment of damaged trees, autumn damage might cause stem quality defects due to disrupted apical growth and reduce tree height due to withered shoot top. A study of simulated spring frost showed height reduction by $26 \%$ for two-yearold poplars (Gudynaitè-Franckevičienè, Pliūra, \& Suchockas, 2020), whereas a study in northern boreal conditions has shown height reduction to exceed $1.35 \mathrm{~m}$ length for poor-performing clones while no or minor reduction for high- and average-performing clones at the age of three years (Schreiber et al., 2013).

Overall, the observed damage had a low effect on clone height performance, as there was a relatively tight correlation between the height of the alive trees (pooled undamaged, autumn frost-damaged, and browsed trees) and undamaged trees (rho $=0.82, \mathrm{p}$ $<0.001)$. Clones significantly $(\mathrm{p}<0.001)$ differed in their height after the first growing season, and their height was from $51 \pm 8$ to $124 \pm 5 \mathrm{~cm}$ for alive trees (Figure 2), and $37 \pm 9$ to $159 \pm 25 \mathrm{~cm}$ for undamaged trees. However, for a few clones damage significantly affected height: for clone AF16 undamaged trees had by $28 \%$ shorter height when all live trees were considered, whereas for clone LV3 undamaged trees were by $39 \%$ higher than all live trees.

Poplars in boreal conditions have to deal not only with the mismatching length of the growing season but also with low minimum temperatures and freeze-thaw events (Schreiber et al., 2013). The clone survival after the first growing season was positively related to survival (rho $=0.80, \mathrm{p}<0.001$ ) at the age of three years. However, the observed winter frost damage showed no relation regarding the proportion of trees with autumn frost damage observed at the age of one year (Figure 3), indicating different underlying mechanisms for these types of injuries and implications for clone selection. As opposed to results of autumn frost injuries, trees with winter frost damage tended to be shorter than trees with no visible damage (Figure 4) and had lower survival (rho $=0.47, \mathrm{p}<0.01)$. Such a trend of clones with low survival to be shorter was observed in boreal Canada and was linked to structural traits of wood, namely, xylem vessel size that also affects tree cold tolerance (Schreiber et al., 2013).

The clonal differences in their height were significant at all studied ages (all $\mathrm{p}<0.001$; Figure 2). Our results of clonal mean at the respective age are in 


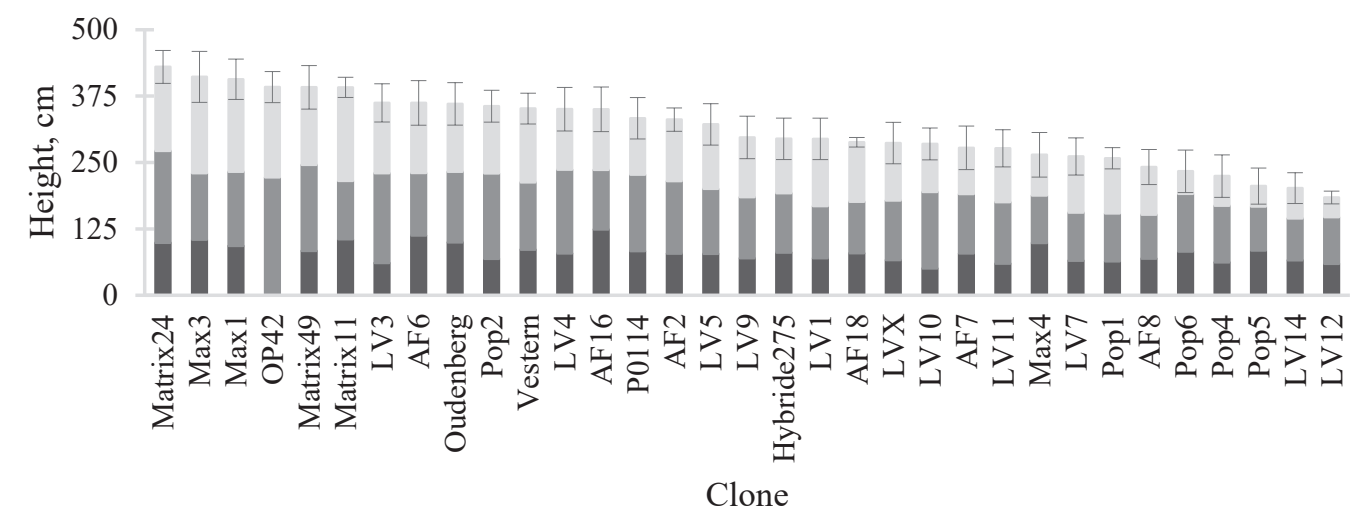

Figure 2. Height at the age of one (dark stacked bars), three (grey stacked bars), and four (light stacked bars; $\pm 95 \%$ confidence interval) years, survival (black bullets) at the age of three years and proportion of autumn frost-damaged trees (white bullets) at the beginning of the second growing season.

a range of mean height of the clone origin groups at the age of three years (166 to $258 \mathrm{~cm}$ ) in Denmark and the age of four years ( 32 to $630 \mathrm{~cm}$ ) in Sweden (Stener $\&$ Westin, 2017). Higher height growth was observed in north-eastern Germany (Landgraf, Carl, \& Neupert, 2020), where 11 clones overlapped with our studied site. After the first growing season clones had height from $1.09 \mathrm{~m}$ to $2.35 \mathrm{~m}$, notably exceeding height performance in our site already after the first season and the difference in height between the studies was even more distant at the age of three years.

The height difference between the highest and lowest clone increased from a magnitude of 2.4 at the age of one year to 2.9 at the age of three years, and such variation across the clones is typically observed in clonal trials (Nielsen et al., 2014; Pliura et al., 2007, 2014). During these two years, clones had moderately

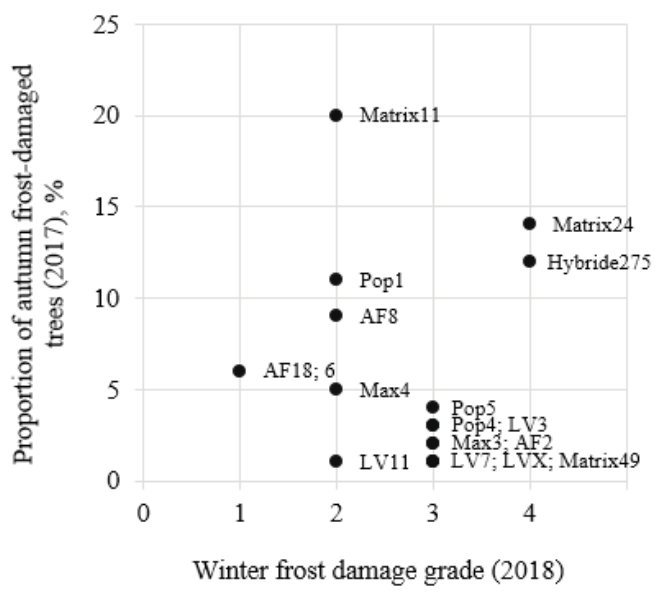

Figure 3. The proportion of autumn frost-damaged trees in the spring 2017 and the winter frost damage grade of the winter 2018. The grades of winter frost damage are as follows: 0 - dead, 1 - severe damage, 2 - mild damage, tree recovers, 3 - minor damage, and 4 - no visible winter frost damage. changed their ranking of height (correlation between height measurements rho $=0.61, p<0.001$; Figure 5a). Variation in ranking at the first few years is related to different growth development strategies, such as to clone ability to establish roots (Zalesny, Riemenschneider, \& Hall, 2005; Zhao et al., 2014) and allometric differences (Karacic et al., 2020) that are determined by clone parental species. Poor or even adverse relation between height growth at the age of one and four years for 37 poplar clones was observed by Stener and Westin (2017). At the age of four years, the difference in height between the highest and lowest clone was slightly decreased. Additionally, the clonal ranking between the age of three and four years was changed less (maximal difference: 20 positions for clone LV3; Figure 5a) than between one and three years (maximal difference: 10 positions for clone Pop6; Figure 5b).

The poplar performance is also affected by genotype $\times$ environment interaction (Pliura et al., 2007), which implies a need for clonal testing in

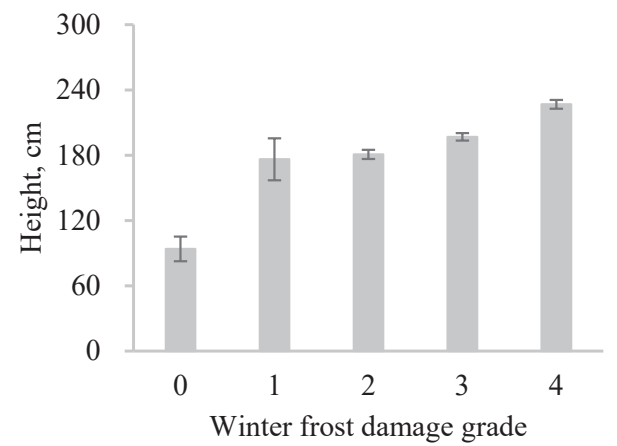

Figure 4. Tree height at the age of three years according to winter frost damage grades of the winter

2018. The grades of winter frost damage are as follows: 0 - dead, 1 - severe damage,

2 - mild damage, tree recovers, 3 - minor damage, and 4 - no visible winter frost damage. 
(a)

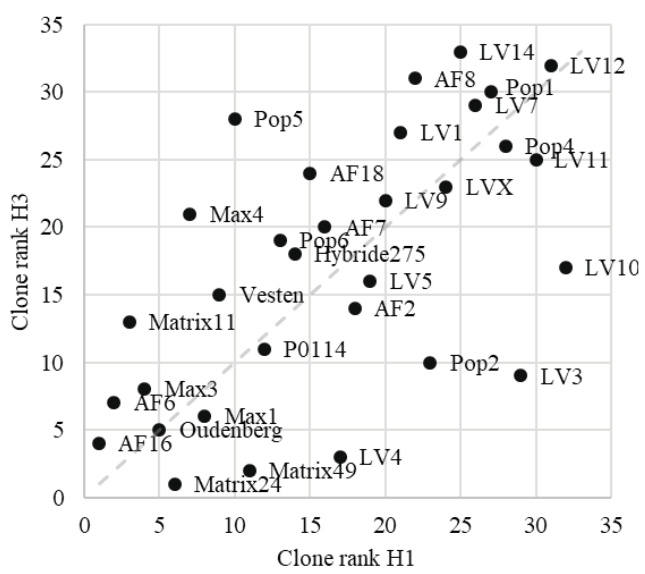

(b)

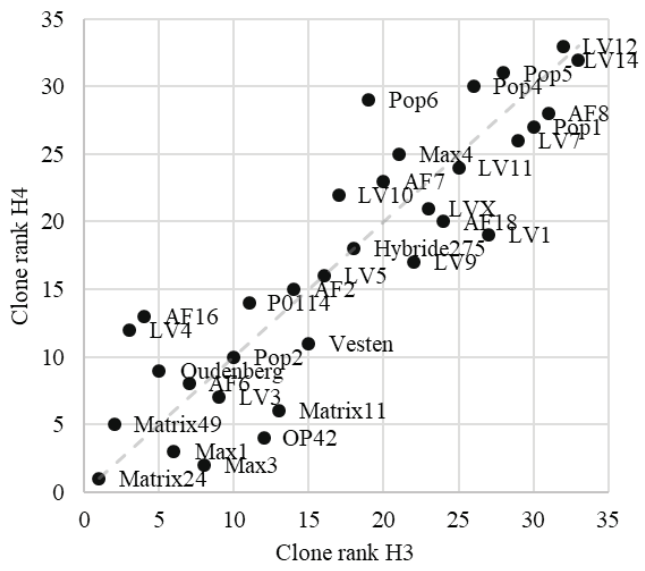

Figure 5. The changes in clone ranking for height (a) between the age of one (H1) and three years (H3) and (b) between the age of three (H3) and four (H4) years. The dashed lines represent the unchanged position of a rank between the different ages. Clones above the line have decreased rank and clones below the line have increased the rank.

various sites also for clones with decent growth. As an example, the clone OP42 was among the best performing clones for height and had reasonable survival in the present study, while in a study of clone OP42 on a frost-prone site all trees had completely withered stems in the spring after the first winter season (Š̄enhofa et al., 2017). On the other hand, the survival after the winter frost for clone Baldo ( $P$. deltoides) was so severe that we removed it from the further measurements. This clone had shown inferior growth also in previous trials in Latvia (Šènhofa et al., 2018), suggesting that further testing and practical use of this particular clone might be inexpedient.

Our results indicate that clones with comparable height growth that are not susceptible to cold injuries might be selected (e.g. clones Max1, Matrix49; Figure 2). Alternatively, for clones Matrix24 and Matrix11, the fast-growth likely compensated the height-loss due to autumn frost damage, as these were among the highest clones at the age of four years. Progenies of the same parental species as clone series Matrix $(P$. maximowiczii $\times P$. trichocarpa) have shown similar results by remaining position among the tallest clones regardless of significant height loss due to stem withering (Gudynaitè-Franckevičienè, Pliūra, $\&$ Suchockas, 2020). The prevalence of benefits over potential losses in growth and survival due to frost damage was observed for ten-year-old $P$. tremuloides clones that were moved as much as $7^{\circ}$ latitude in western Canada (Schreiber et al., 2013).

Alternatively, our results also agree with findings from a previous study (Lazdina et al., 2016), suggesting that suitable tolerance to cold injuries of locally collected clones has not sufficient advantage to gain a higher yield, as compared to highly productive, although more sensitive, introduced clones. Attempts to obtain local planting material are also done in the Czech Republic (Novotná, Štochlová, \& Benetka, 2020). They tested locally selected $P$. nigra genotypes and crossings among their plus trees selected from natural populations with introduced clone Max4 over three rotations, each by three years. Similarly to our results, locally selected clones were inferior, and the best performing local clone had by the quarter lower yield of dry matter than clone Max4 (Novotná, Štochlová, \& Benetka, 2020). The results from a trial in Sweden where 34 clones of different origin were tested showed the most popular 'old' clone in the region, OP 42 , to exceed growth performance by $30 \%$ to $60 \%$ at the age of 12 years of other more recently bred varieties (Karacic et al., 2020).

\section{Conclusions}

The results of this study emphasize the need for clonal testing under the local climatic conditions before recommendations of particular clones for commercial use in Latvia. The results indicate that fast-growing trees (unhardened shoots) are more susceptible to autumn frost damage that reduces height, while trees with poor growth are more likely to be damaged by winter frost that affects survival. Regardless of the large variation among the clones, the best $15 \%$ of clones showed comparable height growth (difference less than 10\%) and reasonable survival, suggesting that several clones with close performance could be selected for commercial use to mitigate both ecological and financial risks. Yet, further monitoring of the clone performance is needed for recommendations to use particular clones at least until they have reached half of the expected rotation age. 


\section{Acknowledgments}

The study was funded by the European Union's Horizon 2020 research and innovation programme, grant agreement No 727698, and Forest Competence
Centre (ERDF) project "Technologies for efficient transfer of genetic gain in plant production and forestry" (1.2.1.1/18/A/004).

\section{References}

Čakša, L., Šēnhofa, S., Šṇepsts, G., Elferts, D., Liepa, L., \& Jansons, Ā. (2021). Effect of stem snapping on aspen timber assortment recovery in hemiboreal forests. Forests 12, 28. DOI: 10.3390/f12010028.

FAO (2016). Poplars and other fast-growing trees - Renewable resources for future green economies. Synthesis of country progress reports. $25^{\text {th }}$ session of the International Poplar Commission, Berlin, Federal Republic of Germany, 13-16 September, 2016. Working Paper IPC/15. Forestry Policy and Resources Division, FAO, Rome.

Friedman, J.M., Roelle, J.E., Gaskin, J.F., Pepper, A.E., \& Manhart, J.R. (2008). Latitudinal variation in cold hardiness in introduced Tamarix and native Populus. Evol. Appl. 1(4), 598-607. DOI: 10.1111/j.17524571.2008.00044.x.

Gailis, A., Jansone, B., Racenis, E., Sisenis, L., \& Jansons, A. (2019). Assessment of silver birch (Betula pendula Roth.) geographical provenances in Latvia. In Proceedingas of 19th International Multidisciplinary Scientific GeoConference: SGEM 19(3.2), 625-632. 29 June - 6 July 2019, Albena, Bulgaria. DOI: 10.5593/sgem2019/3.2/S14.081.

Gailis, A., Samsone, I., Šēnhofa, S. Girgžde, E., Kāpostiņš, R., \& Jansons, Ā. (2021). Silver birch (Betula pendula Roth.) culture initiation in vitro and genotype determined differences in micropropagation. New Forests 52(1), 1-16. DOI: 10.1007/s11056-020-09828-9.

Gudynaitè-Franckevičienè, V., Pliūra, A., \& Suchockas, V. (2020). Ecogenetic plasticity and genetic variation in Populus hybrids under the impact of simulated climate change related stressors. Balt. For. 26(2), 462. DOI: $10.46490 /$ BF462.

Holeski, L.M., McKenzie, S.C., Kruger, E.L., Couture, J.J., Rubert-Nason, K., \& Lindroth, R.L. (2016). Phytochemical traits underlie genotypic variation in susceptibility of quaking aspen (Populus tremuloides) to browsing by a keystone forest ungulate. J. Ecol. 104(3), 850-863. DOI: 10.1111/1365-2745.12559.

Howe, G.T., Saruul, P., Davis, J., \& Chen, T.H.H. (2000). Quantitative genetics of bud phenology, frost damage, and winter survival in an F2 family of hybrid poplars. Theor. Appl. Genet. 101, 632-642. DOI: 10.1007/ s001220051525.

Jansons, Ā., Matisons, R., Baliuckas, V., Puriņa, L., Krišāns, O., Jansons, J., \& Baumanis, I. (2018). Performance variation of lodgepole pine provenances in Latvia. Silva Fenn. 52(5), 10014. DOI: 10.14214/sf.10014.

Jansons, Ā., Zeps, M., Rieksts-Riekstiņš, J., Matisons, R., \& Krišāns, O. (2014). Height increment of hybrid aspen Populus tremuloides $\times$ P. tremula as a function of weather conditions in south-western part of Latvia. Silva Fenn. 48(5), 1124. DOI: 10.14214/sf.1124.

Junttila, O., \& Kaurin, A. (1990). Environmental control of cold acclimation in Salix pentandra. Scand. J. For. Res. 5(1-4), 195-204. DOI: 10.1080/02827589009382605.

Jürgensen, C., Kollert, W., \& Lebedys, A. (2014). Assessment of industrial roundwood production from planted forests. FAO Planted Forests and Trees Working Paper FP/48/E. Rome. Retrieved March 10, 2021, from http://www.fao.org/forestry/plantedforests/67508@170537/en/.

Karacic, A., Adler, A., Weih, M., \& Christersson, L. (2020). An analysis of poplar growth and quality traits to facilitate identification of climate-adapted plant material for Sweden. Bioenergy Res. 1-17. DOI: 10.1007/ s12155-020-10210-y.

Ķēniņa, L., Elferts, D., Bāders, E., \& Jansons, Ā. (2018). Carbon pools in a hemiboreal over-mature Norway spruce stands. Forests 9(7), 435. DOI: 10.3390/f9070435.

Ķēniņa, L., Jaunslaviete, I., Liepa, L., Zute, D., \& Jansons, Ā. (2019b). Carbon pools in old-growth Scots pine stands in hemiboreal Latvia. Forests 10, 911. DOI: 10.3390/f10100911.

Ķēniņa, L., Mača, S., Jaunslaviete, I., \& Jansons, Ā. (2019a). Carbon pools in old-growth Scots pine stands on organic soils and its concentration in deadwood: cases study in Latvia. In A. Raupelienè (Ed.), Proceedings of $9^{\text {th }}$ International Scientific Conference "Rural Development 2019", 26-28 September 2019 (pp. 284288). VDU, Kaunas, Lithuania. DOI: 10.15544/RD.2019.054.

Landgraf, D., Carl, C., \& Neupert, M. (2020). Biomass yield of 37 different SRC poplar varieties grown on a typical site in north eastern Germany. Forests 11(10), 1048. DOI: 10.3390/f11101048.

Lastra, R.A., Kenkel, N.C., \& Daayf, F. (2017). Phenolic glycosides in Populus tremuloides and their effects on long-term ungulate browsing. J. Chem. Ecol. 43(10), 1023-1030. DOI: 10.1007/s10886-017-0895-z. 
Lazdiṇa, D., Šēnhofa, S., Zeps, M., Makovskis, K., Bebre, I., \& Jansons, Ā. (2016). The early growth and fall frost damage of poplar clones in Latvia. Agron. Res. 14(1), 109-122.

Mola-Yudego, B., Arevalo, J., Díaz-Yáñez, O., Dimitriou, I., Freshwater, E., Haapala, A., Khanam, T., \& Selkimäki, M. (2017). Reviewing wood biomass potentials for energy in Europe: the role of forests and fast growing plantations. Biofuels 8(4), 401-410. DOI: 10.1080/17597269.2016.1271627.

Nielsen, U.B., Madsen, P., Hansen, J.K., Nord-Larsen, T., \& Nielsen, A.T. (2014). Production potential of 36 poplar clones grown at medium length rotation in Denmark. Biomass Bioenerg 64, 99-109. DOI: 10.1016/j.biombioe.2014.03.030.

Niemczyk, M., Kaliszewski, A., Jewiarz, M., Wróbel, M., \& Mudryk, K. (2018). Productivity and biomass characteristics of selected poplar (Populus spp.) cultivars under the climatic conditions of northern Poland. Biomass Bioenerg 111, 46-51. DOI: 10.1016/j.biombioe.2018.02.002.

Novotná, K., Štochlová, P., \& Benetka, V. (2020). Verification of new Populus nigra L. clone improvement based on their performance over three rotations. iForest 13(3), 185. DOI: 10.3832/ifor3171-013.

Pawson, S.M., Brin, A., Brockerhoff, E.G., Lamb, D., Payn, T.W., Paquette, A., \& Parrotta, J.A. (2013). Plantation forests, climate change and biodiversity. Biodivers. Conserv. 22(5), 1203-1227. DOI: 10.1007/ s10531-013-0458-8.

Pliura, A., Suchockas, V., Sarsekova, D., \& Gudynaite, V. (2014). Genotypic variation and heritability of growth and adaptive traits, and adaptation of young poplar hybrids at northern margins of natural distribution of Populus nigra in Europe. Biomass Bioenerg 70, 513-529. DOI: 10.13189/ujps.2015.030602.

Pliura, A., Zhang, S.Y., MacKay, J., \& Bousquet, J. (2007). Genotypic variation in wood density and growth traits of poplar hybrids at four clonal trials. For. Ecol. Manag. 238(1-3), 92-106. DOI: 10.1016/j. foreco.2006.09.082.

Rytter, L., \& Stener, L.G. (2014). Growth and thinning effects during a rotation period of hybrid aspen in southern Sweden. Scand. J. For. Res. 29(8), 747-756. DOI: 10.1080/02827581.2014.968202.

Rytter, L., Johansson, K., Karlsson, B., \& Stener, L.G. (2013). Tree species, genetics and regeneration for bioenergy feedstock in northern Europe. In S. Kellomäki, A. Kilpeläinen \& A. Alam (Eds.), Forest bioenergy production (pp. 7-37). Springer, New York, NY.

Samariks, V, İstenais, N., Seipuli,s A., Miezīte, O., Krišāns, O., \& Jansons, Ā. (2021). Root-soil plate characteristics of silver birch on wet and dry mineral soils in Latvia. Forests 12, 20. DOI: 10.3390/f1201002.

Samariks, V., Brizga, D., Rūba, J., Seipulis, A., \& Jansons, Ā. (2020). Root-plate characteristics of common aspen in hemiboreal forests of Latvia. Forests 12, 32. DOI: 10.3390/f12010032.

Schreiber, S.G., Hamann, A., Hacke, U.G., \& Thomas, B.R. (2013). Sixteen years of winter stress: an assessment of cold hardiness, growth performance and survival of hybrid poplar clones at a boreal planting site. Plant Cell Environ. 36(2), 419-428. DOI: 10.1111/j.1365-3040.2012.02583.x.

Šēnhofa, S., Neimane, U., Grava, A., Sisenis, L., Lazdiṇa, D., \& Jansons, A. (2017). Juvenile growth and frost damages of poplar clone OP42 in Latvia. Agron. Res. 15(5), 2113-2125.

Šēnhofa, S., Zeps, M., Gailis, A., Kāpostiņš, R., \& Jansons, Ā. (2016). Development of stem cracks in young hybrid aspen plantations. For. Stud. 65, 16-23. DOI: 10.1515/fsmu-2016-0008.

Šēnhofa, S., Zeps, M., Ķēniņa, L., Neimane, U., Kāpostiņš, R., Kārkliṇa, A., \& Jansons, A. (2018). Intra-annual height growth of hybrid poplars in Latvia. Results from the year of establishment. Agron. Res 16(1), 254-262.

Skrøppa, T., \& Magnussen, S. (1993). Provenance variation in shoot growth components of Norway spruce. Silvae Genet. 42, 111-120.

Stener, L.-G., \& Westin, J. (2017). Early growth and phenology of hybrid aspen and poplar in clonal field tests in Scandinavia. Silva Fenn. 51(3), 5656. DOI: 10.14214/sf.5656.

Sulaiman, C., Abdul-Rahim, A.S., \& Ofozor, C.A. (2020). Does wood biomass energy use reduce $\mathrm{CO}_{2}$ emissions in European Union member countries? Evidence from 27 members. J. Clean. Prod. 253, 119996. DOI: 10.1016/j.jclepro.2020.119996.

Zalesny, R.S., Riemenschneider, D.E., \& Hall, R.B. (2005). Early rooting of dormant hardwood cuttings of Populus: analysis of quantitative genetics and genotype $\times$ environment interactions. Can. J. For. Res. 35(4), 918-929. DOI: 10.1139/x05-018.

Zeltiņš, P., Katrevičs, J., Gailis, A., Maaten, T., Desaine, I., \& Jansons, Ā. (2019). Adaptation capacity of Norway spruce provenances in Western Latvia. Forests 10, 840. DOI: 10.3390/f10100840.

Zeltiňš, P., Katrevičs, J., Gailis, A., Maaten, T., Jansons, J., \& Jansons, Ā. (2016). Stem cracks of Norway spruce (Picea abies (L.) Karst.) provenances in Western Latvia. For. Stud. 65, 57-63. DOI: 10.1515/fsmu-2016-0012.

Zhao, X., Zheng, H., Li, S., Yang, C., Jiang, J., \& Liu, G. (2014). The rooting of poplar cuttings: a review. New For. 45(1), 21-34. DOI: 10.1007/s11056-013-9389-1. 